\title{
Challenging hydro-hegemony of India: resistance of Nepal in the Upper Karnali and Saptakoshi dam project
}

\author{
Promod Tandan ${ }^{1}$
}

Received: 28 October 2020 / Accepted: 7 October 2021 / Published online: 31 October 2021

(c) The Author(s) 2021

\begin{abstract}
The hydropolitical interaction of Nepal and India can be well defined within the framework of hydro-hegemony. Two case studies of hydro-hegemony and counter-hegemony are illustrated in this paper, unleashing the approach of resistance from the vantage point of Nepal: Upper Karnali and Saptakoshi high dam. Both case studies share a common norm that Nepal, as a small state, has been providing access to the Indian hydro-hegemony, which has compelled it to slowly cede its rights from its water resources. As such, in a historical manner, Nepal is not only losing the opportunity of capitalising on its water resources, but also fixing itself in a vulnerable position in terms of the water securitisation. However, for the two projects lying entirely within the (political) territory of Nepal, the state-level resistance is still feasible to deter and deflect the unintended detrimental effect on Nepal.
\end{abstract}

Keywords Nepal $\cdot$ India $\cdot$ Hydro-hegemony $\cdot$ Upper Karnali $\cdot$ Saptakoshi high dam $\cdot$ Resistance $\cdot$ Resource nationalism

\section{Introduction}

Environmental issues are increasingly being embraced within the broadening definition of the term 'security' ${ }^{1}$ (Gleick 1993; Frohlich 2012). However, the water resource features a unique characteristic in that on the contrary to the general celebration of the environmental issues as the transnational disposition, water attainment is viewed through the nationalistic frame (Bremmer and Johnston 2009). When the hydropolitical interaction occurs between two or more sovereign states within a hydropolitical system, power functions as an incessant, influential, and decisive attribute, which is selectively articulated and interpreted to the notion that the denounce of colonialism is made subverting the notion of the world society.

The existing (power) ${ }^{2}$ inequalities are successively resonated within the (water) treaties that in a way comply with the hydro-hegemon's interest, and in another effectively provide the access for utilising the utilitarian mechanisms or soft power for attaining weaker riparian's compliance (Zeitoun and Warner 2006). In the context of such 'power-over'

Promod Tandan

promodtandan@gmail.com

1 University of Westminster, London, UK being exercised over small states-even in the case when the water resource lying entirely within their territory, it is of immense necessity to represent the voice of small states that, to some extent, underpins their sensibilities operationalised in a way that eschews the conventional dichotomy of hydropolitical conflict and cooperation. Thus, the paper intends to critically interrogate the hydropolitics through the (resistive) perspective of Nepal in relation to India through the two case studies of Upper Karnali hydropower project (UKHP) and Saptakoshi multi-purpose high dam project (SHDMP) lying within the territory of Nepal that engender the plausibility of imposing detrimental effects to Nepal.

Nepal, a small state lying between India and China within the Himalayan region is considered rich in terms of the water resources with more than 6000 stream, rivers and rivulets, including four large rivers Koshi, Gandaki, Karnali, and

\footnotetext{
1 "The earliest references to national security included concerns about economic issues, the strength of domestic industry, and the proper correlation of all measures of foreign and domestic policy", whereas now environmental or ecological security has been a significant element in international security (Gleick 1993, p. 81).

2 Here, power is considered both structural and other more subtle forms of power mechanisms straddled over the social, cultural, politi$\mathrm{cal}$ and the resource economy. The subtle mechanism includes sanctioning discursive processes, constructing knowledge, and finalising the treaties and agreements to protect the bigger power interest.
} 
Mahakali, which contribute almost $75 \%$ flow in Ganges ${ }^{3}$ (Pun 2008). As such, Nepal's hydropower potential (theoretically 83,000 MW) (Shrestha 2017) is envisioned as a game-changer in terms of its affordability to offer a convenient and significant supply of 'clean' energy to meet Nepal's domestic and neighbouring India's accelerating needs as generated through the large-scale hydropower storage projects by augmenting the low flow (in dry season), and regulating the high flow (in monsoon season). But, instead of attempting to internally harness the potential of its water resources, Nepal, instead, has entered in several hydropolitical interactions with India in the form of the hydropower agreements, of which the two case studies are selected to get a critical insight on the way the hydropolitical interaction is configured:

1) Upper Karnali hydropower project (UKHP): Since the recognition of its feasibility in 1960 , this project has often been referred as the 'jewel' of the crown, due to its cost, construction efficiency and hydropower potentiality. However, ironically, decreasing the production capacity from 4180 to $900 \mathrm{MW}$, the UKHP project agreement was made with GMR (Gandhi Mallikarjuna Rao) company of India on September 2014 (during the visit of Indian Prime minister Modi) to comply with the Indian interest (Pun 2014) (Fig. 1).

2) Saptakoshi high dam multipurpose project (SHDMP): $\mathrm{Koshi}^{4}$ (Saptakoshi) river is made up of the integration of seven tributaries like Tamor, Arun, Likhu, Indrawati, Sunkoshi, Tamakoshi and Dudhkoshi, which is the largest river of Nepal (Linkha 2020). To unilaterally harness its potential, British-India had designed a multipurpose project to be constructed in Nepal in 1946. Inheriting the British legacy, India, ${ }^{5}$ to some extent, has successfully controlled floods in Bihar through the construction of an embankment called the Koshi barrage under the bilateral Koshi agreement in Nepal in 1954. Since 1991, as a part of its river linking project(s), India has been interested in constructing a multipurpose dam in the Koshi river that

\footnotetext{
3 The Ganges or Ganga (length of $2525 \mathrm{~km}$ ) is a prominent river of Asia, which flows through India and Bangladesh. The river rises in the western Himalayas in the Indian state of Uttarakhand that flows south and east through the Gangetic plain of India and Bangladesh, eventually emptying into the Bay of Bengal (Shrestha 2017).

${ }^{4}$ Considered as 'sorrow of Bihar', Koshi river is famous for changing its route (Shah 2018).

5 Initially designed by British-India that gained currency after 1970s, the river linking project is intended to effectively manage water resources in India by linking Indian (and Nepali) rivers by a network of reservoirs and canals to address. The Inter-link project has been split into three parts: a northern Himalayan rivers inter-link component (14 projects), a southern Peninsular component and starting 2005 (16 projects), an intrastate river linking component (37 projects) (Pun 2008).
}

remained dormant till 2008. However, with the heavy flood in $2008,{ }^{6}$ a part of the embankment collapsed, displacing millions of people in Nepal and India, which led to the re-emergence of the concept of building a multipurpose dam in Nepal. Specifically, the project proposes a dam (height: $269 \mathrm{~m}$; reservoir of $195 \mathrm{~km}^{2}$, estimated power generation of $3300 \mathrm{MW}$ ) towards the Northern side in the upstream of Koshi river that consists of the two channels of east and west intended to convey water to Nepal and India, respectively (Shah et al. 2007) (Fig. 2).

These two projects carry a special significance in relation to the extent of the gap between the potential return and initial investment, whereby the projects have been unilaterally designed to fulfil the water needs of India to be constructed within the territory of Nepal. For decades, Nepal has shelved the blueprint of the UKHP project inclined to its national interests. Whereas, regarding the SHDMP project, Nepal has yet to assess the project's significance and seemingly the extent of the detrimental effects. Here, an obvious question arises: Why Nepal is eager to engage in those hydropolitical interactions despite all these facts? The answer lies in the variegated aspects of the power play that defines the overall hydropolitical configuration between India and Nepal.

Power has been considered as the major influential factor on the (transboundary) water interaction, that not only determines the 'control' of the water resources (Hanasz 2014, p. 98), but also determines the potential outcome through the political process (Zeitoun and Mirumachi 2008; Cascão 2009); as Swyngedouw (2009, p. 58) puts it, "when two equal rights meet, power decides". The constitutive role of power is to the extent that even the upstream/downstream dynamic is predicated on power; those upstream use water to get more power, and those downstream use power to get more water" (Zeitoun and Warner 2006, p. 436, 442). Primarily, four important factors have been identified that play constitutive role in a transboundary water interaction: degree of scarcity; extent of water shared by states/region; relative power; ease of access to alternative water sources (Gleick 1993, p. 84). Here, compared to other constant factors focussing around resource availability, the only variable factor is the power disparity, which signifies its imperative role to steer the hydropolitical configuration rather than the resource itself.

In this way, power asymmetry can shape the outcome of the transboundary water interactions in favour of the hydrohegemon, which can not only create a pivotal knowledge construction but also can provide order and leadership,

\footnotetext{
${ }^{6}$ The efforts to restart the dam planning and construction began in 2008 with the initiation of India and Saptakoshi joint commissions (Linkha 2020).
} 
Fig. 1 The Upper Karnali Hydroelectric Project Site, straddled across three districts, Surkhet, Achaam, and Dailekh (NESS 2012)

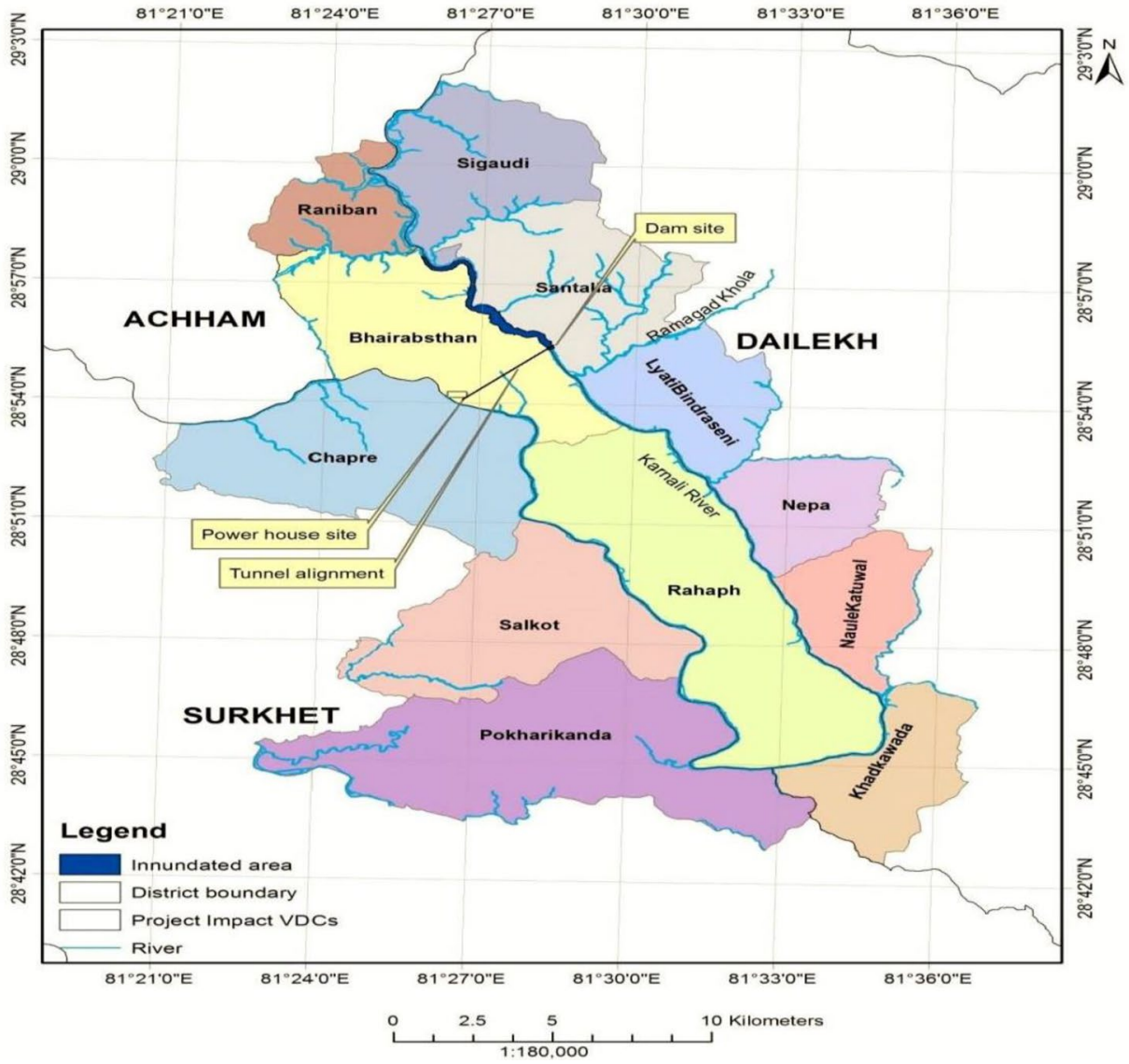

but at the expense of the weaker one (Zeitoun and Warner 2006; Zeitoun and Allan 2008, p. 3). Hydro-hegemony ${ }^{7}$ (Hegemony connoting domination and coercion) is used when one state within a shared river basin asserts its power over other riparian states irrespective of the riparian position and seeks to enforce its interest (Zeitoun and Warner 2006). The important point here is that on this course, the small state's voice is either muted due to the existing conflict (with the dominance of hydro-hegemon) between the riparians or the conflict is mislabelled as cooperation (see Selby 2003). As such, the discourses of conflict and cooperation need critical interrogation in terms of comprehension and inclusion. Therefore, it is necessary to shift away from the hydrohegemonic sensibilities to properly address the notion of water scarcity for more secure and stable hydropolitical relations. Thus, developing a conceptual frame that facilitates interpretation of the features of the dynamic hydropolitical

\footnotetext{
${ }^{7}$ Hydro-hegemon can lead to two types of interactions: positive (when hydro-hegemon directs in integrated manner) and negative (unilateral and using resource capture strategies) (Zeitoun and Warner 2006). Accordingly, hydro-hegemony theory posits that the configuration of nature of water interaction greatly depends on the direction of hydro-hegemon's interest (ibid.).
}

interaction, the paper intends to illuminate the way the small states construct, react and resist the hydro-hegemony, ensuring their rights and voices.

\section{Hydropolitics as conventionally understood in conflict-cooperation terms}

The negative correlation between the rising water demand and uneven and dwindling water reserves has induced a historic concern over the access, usage, and control over the water resources that has a direct bearing over the norms of the hydropolitical relation vis-a-vis security, water fuelled diplomacy and the interstate relationships. However, throughout the history, water resource has often been mismanaged, misallocated, undervalued and squandered by many societies (Zeitoun et al. 2010; Mirumachi 2015; Shrestha 2016; Nagheeby and Warner 2018). The historical trajectory of the scholarship in water politics suggests that the hydropolitics has gained currency since late 1980s, when water obtained attention as one of the major elements for conflict, social and economic disruptions (Mollinga 2008; Morrisette and Borer 2013). It alludes that the pioneering studies on hydro-politics have primarily been focused on the 
Fig. 2 Coverage of water dammed due to high dam in Arun river basin (Source: Linkha 2020)

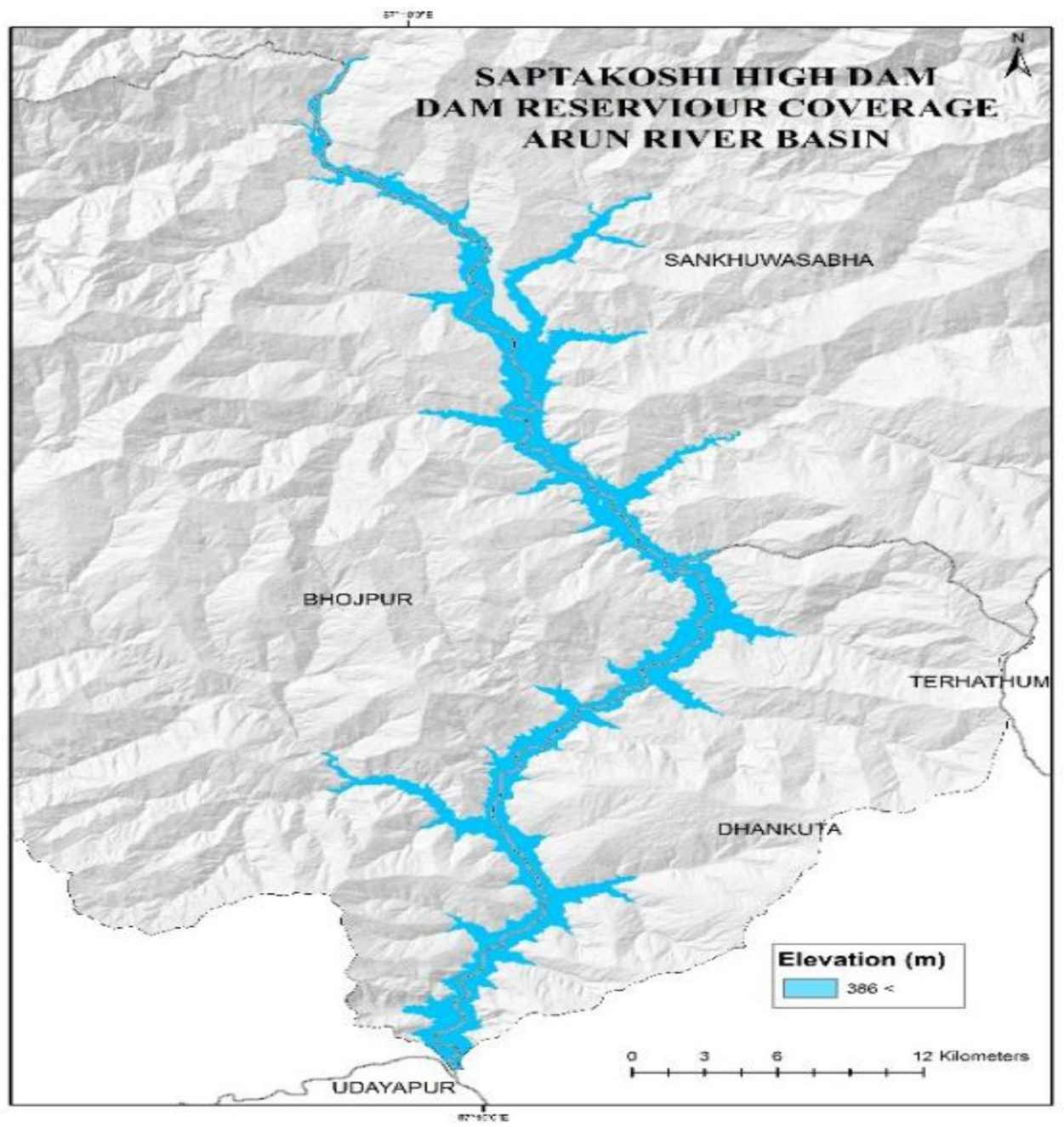

critical inquiry of the riparian state relationship sharing a transboundary watershed to be dominated by the narratives of conflict and cooperation (Gleick 1993; Dinar 2002).

That amid the increasing population, looming climate change issues, and the escalating rate of competition for the limited amount of water, scholars have categorised various factors responsible for the stimulation of conflictual interaction. There is a consensus that the likelihood of conflict is compounded by various factors like scarcity, location and construction of dams, historic and existing political, national and religious tensions in the region (Mollinga 2008; Waslekar 2011; Lufkan 2017). In a significant manner, the transboundary water interactions have also been defined within the discourse of scarcity and abundance. In the former case, the interaction is supposedly expected to be on the competition over greater flow volume, whereas on the latter, the interaction is presumed to be focussed on the control of the flow of hydropower and the control for the flood management purposes; the control for flood management is often associated with the attainment of politically linked non water goals. But in either of the cases, the competition for fulfilling the riparian states interests has been surmised as an inevitable ramification thus implying that the conflictual interaction is inevitable. Against the backdrop of increasing concern on water scarcity and the subsequent prevalence of the 'water stress' (coined by Falkenmark, 1989 in Wolf 1998), there are speculations over the metamorphosis of the occasional intense political instability (at a small scale) into the form of acute violence between tribe, interest groups and states (Wolf 1998, p. 251, 252). Accordingly, amid the global water scarcity and the subsequent conflict, there is increasing trepidation about the possibility of 'water wars'. However, notably, there is a fallacy in the argument of water war due to the espoused excessive focus over the notion of sheer political tensions or stability than on water warfare that objectivises water as a tool, target, or victim of armed conflict. Furthermore, the utilization of water can neither easily nor quickly be converted into power, for which in spite of numerous water disputes (and conflicts) at local and regional level, war over water is neither strategically rational, hydrographically effective nor economically viable (Wolf 1998; Barnaby 2009). Mahlakeng (2019), overlapping 
Homer-Dixon's Environmental scarcity and the Regime theory affirms the indispensable role of environmental quantity and quality for the prevalence of a conflict for which there is a necessity of envisioning hydropolitics as a change in the hydropolitical system inextricably linked to the institutional capacity to absorb such change.

In the recent decades, cooperation in transboundary water resources has increasingly gained scholarly attention in the discourse of hydropolitics. Needless to say, amid the increasing debate on the discourse related to the transboundary environmental issues and conflicts, cooperation in water resources can be considered the most sustainable option. Yoffe et al. (2003) have paved the avenue for the consideration of conflict and cooperation in a single continuum convenient for the measurement. Taking reference of studies from 1948 to 1999, Yoffe et al. $(2003)^{8}$ came up with a conclusion that the majority of the transboundary agreements were cooperative in nature for which water quantity, quality, joint management and hydropower have played a major role. In line with this, scholars argue that joint management and technical cooperation largely enhance the prospect of cooperation. Taking it as a reference point, Renner $(2009)^{9}$ has outlined the determinant role of attitude for escalating conflict or enhancing collaboration. To put it succinctly, the literatures in hydropolitics vary from considering (irrational individual) conflict and (rational collective) cooperation within a single continuum (like Yoffe et al. 2003) or the coexistence of conflict and cooperation with the prescription of the robust political economy necessary for the transboundary water management (like Mirumachi and Allan 2007; Mirumachi 2015).

But, a visible gap within those prescriptions marks them as parochial and ill-equipped to address the contemporary hydropolitical issues. With the increasing concern over the secure attainment, riparian rights, resource control, management and governance of scarce water resources, the economic condition is also subjected to the strategic importance to the volatility of water (Morrisette and Borer 2013). Therefore, the significance of water (mainly rivers) is compounded with its transformation into as a competitive strategic element; which marks a translation into a political organisation.

\footnotetext{
8 Yoffe et al. (2003) studied 1831 instances of transboundary fresh water interaction over that time period (including unofficial verbal exchange to economic agreement and military action) and listed those water interactions as: cooperation (67\%), conflictive (28\%) and neutral or insignificant (5\%) with no formal declaration of war over water.

9 Renner (2009) has stated that mutual suspicions and reluctance to cooperate between riparians may impair timely approaches to the collective action problems of the non-traditional security threats like water conflict.
}

As such, the consideration of hydropolitics within the parochial continuum of conflict and cooperation only reflects a part of the dynamism of hydropolitics that risks assigning narrow description and reasoning on how water becomes political. Equally, the tendency of labelling conflict or cooperation absolves a hydropolitical interaction from the norms of regional common interest and integrative flow of water (river) resources that severely downplays the aspiration of water allocation in an equitable and benefit sharing manner. Finally, such consideration makes it difficult to represent the hydropolitical dynamics of relations over time and changed political context creating a deterministic rhetoric that (all) 'conflict is bad' and (all) 'cooperation is inherently good'. For instance, considering the transboundary water projects of Nepal with India, Shrestha (2016) reveals that India has been successful in irrigating about 12,200,000 acres of land, mitigating flood hazards, and subsequently receiving other intangible benefits. ${ }^{10}$ On the contrary, Nepal is able to irrigate only 160,000 acres of irrigation facility (that accounts only $1.3 \%$ of total irrigation benefits), leaving aside the social, ecological and economic impacts; Needless to refer that all those projects were constructed within the territory of Nepal. However, conflicting with such ground reality, scholars like Hanasz (2014) argue that Nepal's problematic projects with India were entered by consent rather than coercion. In line with this, Mirumachi (2015) indicates that the water resource projects of Nepal and India have been cooperative. This is what Selby ${ }^{11}$ (2003) fears about that within the much-lauded focus on 'cooperation', it might be the potential repackage of the existing patron-client relationship on the ongoing domination that beset cooperation in the water arena.

Dombrowski (2003, in Zeitoun and Mirnumachi 2008) has stated this as 'disguise of cooperation'. Further, Jägerskog and Zeitoun (2009, p. 7) have argued that as some cooperation can be coercive; thus, it is necessary to view cooperation from the perspective of attaining the goals of riparians that ensures equal participation and decision-making power than the goal in itself. In fact, the word 'cooperation' (and conflict) rather than implying objective and absolute meaning is subjected to the dynamic interpretations. $\overline{10}$ For example, in the Koshi barrage project, India is successful in providing the irrigation benefits to 2,400,000 acres of its land, whereas Nepal is able to irrigate only 60,000 acres of land area. Moreover, due to the reason that the dam lying in Nepali side, huge tracts of fertile land and settlement have been lost where the victims are left without any compensation (see Shrestha 2016).

11 As per Selby (2003, p. 137), cooperation, rather than being the pragmatic and material set of solution and antithesis of 'domination', refers to the discursive condition that arises and exists as the basis of single tacit rule leaving the space for the stipulation that rotates around the power asymmetry. 
For Nepal, cooperation has posed a discursive platform that underplays the space for the alternative water management practices or policies and rather gets entrapped within the rhetoric of cooperation, peace, and breakthrough subsequently subverting the notions of benefit-sharing, and the integrative flow of water that masks the negative effect of power asymmetries. However, it does not simply mean the absence of any sort of resistance or the continuous interaction to retain the water rights.

In her study about the UKHP project, Butler (2016) though remarks about Nepal's long-running tensions about the project with India, but has remained silent on Nepal's aspects of resistance. Likewise, scholars like Shah et al. (2007), Oza (2014), and Linkha (2020), though have highlighted the negative effects of the SHDMP project and the local level resistance, remained silent on the way Nepal has been resistive. Similarly, Gupta (2008) in his venture of outlining the resistive norms has fallaciously presumed the monetary compensation as an adequate form of compensation to the local populations. A step ahead, Shaurabh (2012) has reduced resistance to mutual distrust and local environmental effects. In general, the common theme shared by those scholarships is the way they focus on power in a Gramscian sense, typically on a hydro-hegemony and its interests. In this context, the project of de-parochialising hydropolitics endeavours to evade the conventional discourse of conflict and cooperation and elucidate the small states like Nepal's resistance prevalent within the intellectual, political, and social sphere. This paper aims to partly fill this empirical gap by providing insight into the counter hegemonic strategies.

\section{India as a hydro-hegemon and Nepal}

This section intends to underscore that the hydropolitical interaction is not natural and an abrupt formation; rather it is a composite function of the various factors where the relationship among the origin, action, and the outcome is successfully established. Primarily, four important factors have been identified that play constitutive role in a transboundary water interaction: degree of scarcity; extent of water shared by states/region; relative power; ease of access to alternative water sources (Gleick 1993, p. 84). Here, compared to other constant factors focussing around resource availability, the only variable factor is the power disparity, which signifies its imperative role to steer the hydropolitical configuration rather than the resource itself.

The existing power asymmetry affects the overall phenomenon and process of a water interaction, eventually influencing the origin, approaches and outcomes of the hydropolitical interaction. It infers that the hydropolitical performance is not innocent but implicated in the hydro-hegemon's will to power, and its neo-colonial adventure. Thus, the asymmetry of productive power is a common trait shared by these hydropolitical encounters. It is not only the non-hydro-hegemon who is subject to and subjected to the process; even the hydro-hegemon can be affected with the hydropolitical interaction, specifically when they lie downstream. As such, hydro-hegemon, rather than an inherent and incessant privilege, is also the function of the constructs of the process constituting the geopolitical disposition. Hydro-hegemony maintains the hierarchical position resting on three pillars-power (political, economic, military), riparian position, the potential for water resource exploitation (Zeitoun and Warner 2006, pp. 451-452). Here, the only constant pillar of hydro-hegemony is the riparian position implying that the power asymmetry plays a constitutive role in terms of origin and outcome of a hydropolitical interaction. Hydrohegemons pose a full range of strategic and compliance generating mechanisms with a capability to shape the water flow regime compared to their small counterpart, providing them the leverage of practising the unilateral form of resource exploitation.

This can be observed in the two case studies between Nepal and India, where there are obligations for Nepal to comply with the Indian interests facilitating for the employment of the utilitarian mechanisms or soft power to attain such compliance. Nepal, as an upper riparian, ought to enjoy the inherent geopolitical leverage than downstream India. But the existing power asymmetry has largely affected the overall Indo-Nepal hydropolitical configuration, for which Nepal has been a victim in a doubly manner. Primarily, it is on the verge of external exploitation of its water resources. On the other, owing to its water resources, it is compelled to experience the pressure from India to construct the various infrastructural projects, like dam and embankments. This is a form of inappropriate and destructive form of water governance, which according to Gibbs (2009, p. 2964) is the adventure of the colonial ideology that mutes or excludes the weaker stakeholder.

In the context of the hydropolitical interaction, it is relevant to follow Doty's (1996) notion of imperial encounter, that convey the notion of 'asymmetrical encounter, entailing two basic features, one entity is not only able to construct 'realities', taken seriously and acted upon, but also hold the potential for the resource control, with the other entity being denied equal degrees or kinds of agency and prone to lose the control and authority over its resources. As a political process, transboundary water interaction is besought by interest and power games serving strategic purpose which inherently draws on the notion of the power asymmetry. Thus, the hydropolitical interaction espouses the variegated forms of the structural composition and practice, which conceives the specific interaction, thus 


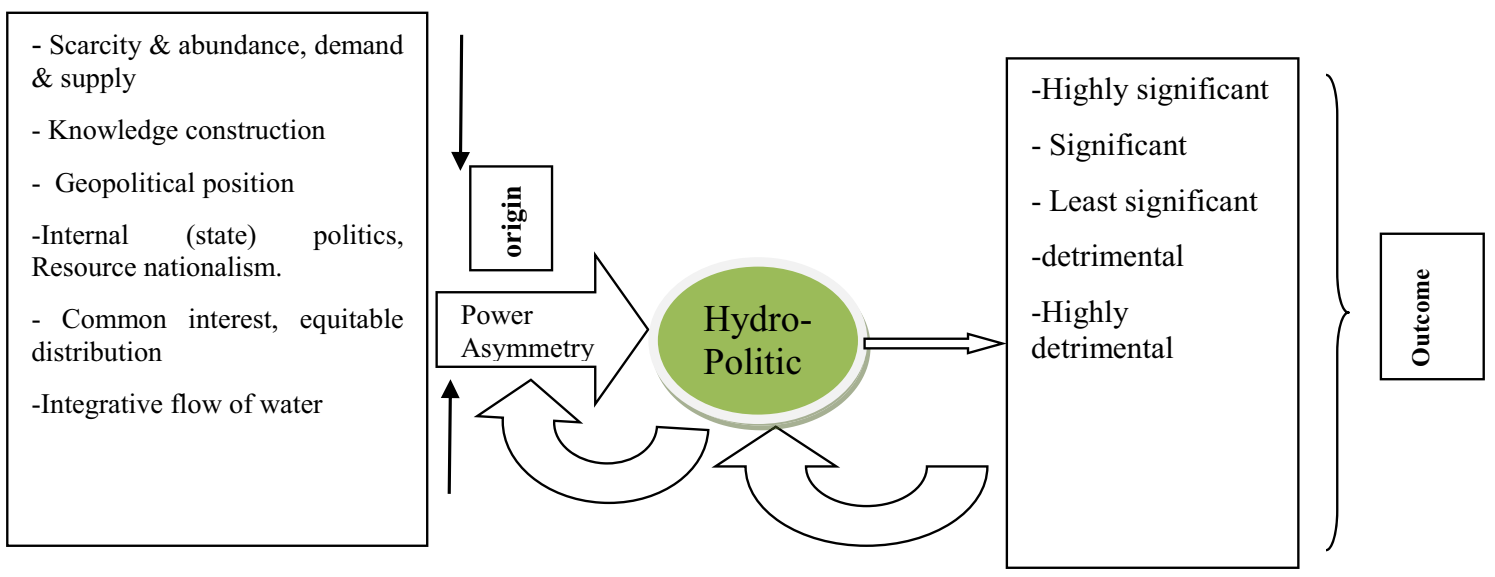

Fig. 3 The overall configuration of hydropolitics (Source: Author)

effectively denying the homogeneity of the hydropolitical disposition. The structural composition mainly includes the extent of scarcity and abundance, demand and supply, knowledge construction, common interests, geopolitical position, internal state politics, integrative flow of water, and resource nationalism (as discussed in the next section). This is emblematic of heterogeneity of the geopolitical nature of the basin and the state that determines the overall use, utility, utilization, conservation, and exploitation of the water resources.

For this reason, the presumed homogenous consideration of the hydropolitical interaction as engendered within the paradigm of conflict and cooperation is refutable that deliberately eschews the dynamism of the engendered specificities. Because, the norm favourable to the hydrohegemon is installed as 'standard' versions in relation to the perception, activities and practices, which in turn, facilitates for the control of the overall hydropolitical outcome, subsequently marginalizing all variants. ${ }^{12}$ This means that the outright temptation to label an interaction as conflictual or cooperative becomes a service favouring the hydro-hegemon, which has directed the outcome allowing a marginal space on account of a small state.

This necessitates the allocation of a space for small states that solicits for the consideration of the hydropolitical interaction through the vantage point of a 'significance' to a small state. This is an endeavour of unleashing the persisting hidden forms of experiences or compromises (of a small state), and partly contribute to the partiality of the conventional teleological consideration of the hydropolitical interaction. The contour of hydropolitics, in fact, is not an abrupt formation; neither exists in a vacuum, but it is the product of the structural composition of the basin, which

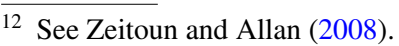

is dependent on the overall nature including the origin and outcome. These factors are equally determinant of the presence of the external interest and overall capability to counter or resist the existing hydro-hegemony (which is the theme of the discussion in the next section). The discernible hydropolitical interaction is the product of various phases of origin, action/interaction, and the outcome, whereby the knowledge on the overall configuration, including the origin, implicates better control of the outcome. This is illustrated in Fig. 3.

Figure 3 attempts to outline the constitutive factors responsible for the origin of the hydropolitical interaction through the reference point of a small state; the outcome is dependent on the index of significance to the small state in the case when the water resource lying entirely (or majority of) within the territory of a small states. The hydropolitical interactions of Nepal with India depict a perfect example of how a 'national water reserve' is transformed to a transboundary hydropolitical interaction. This means that the hydropolitical configuration of Nepal has been dependent on its geopolitical positioning, external water-related interests, domestic needs and the internal political and social context, which implies that the water resources agreements have had been an optional than an obligatory issue for Nepal; favoured by the power asymmetry. Here the question arises that if this is the origin, what is the outcome that is conciliatory to the small state? The answer lies on the index of significance, which determines the extent that a specific hydropolitical interaction is subject to the interrogation through the vantage point of a small state. In line with this, from the view point of a small state, the hydropolitical interaction can be categorised as highly significant, significant, least significant, detrimental and highly detrimental. For better insight on the significance of a small state, the metric system for the significance is categorised in Table 1.

Table 1 effectively illustrates the meaningful inclusiveness of the voice of a small state that fairly celebrates the 


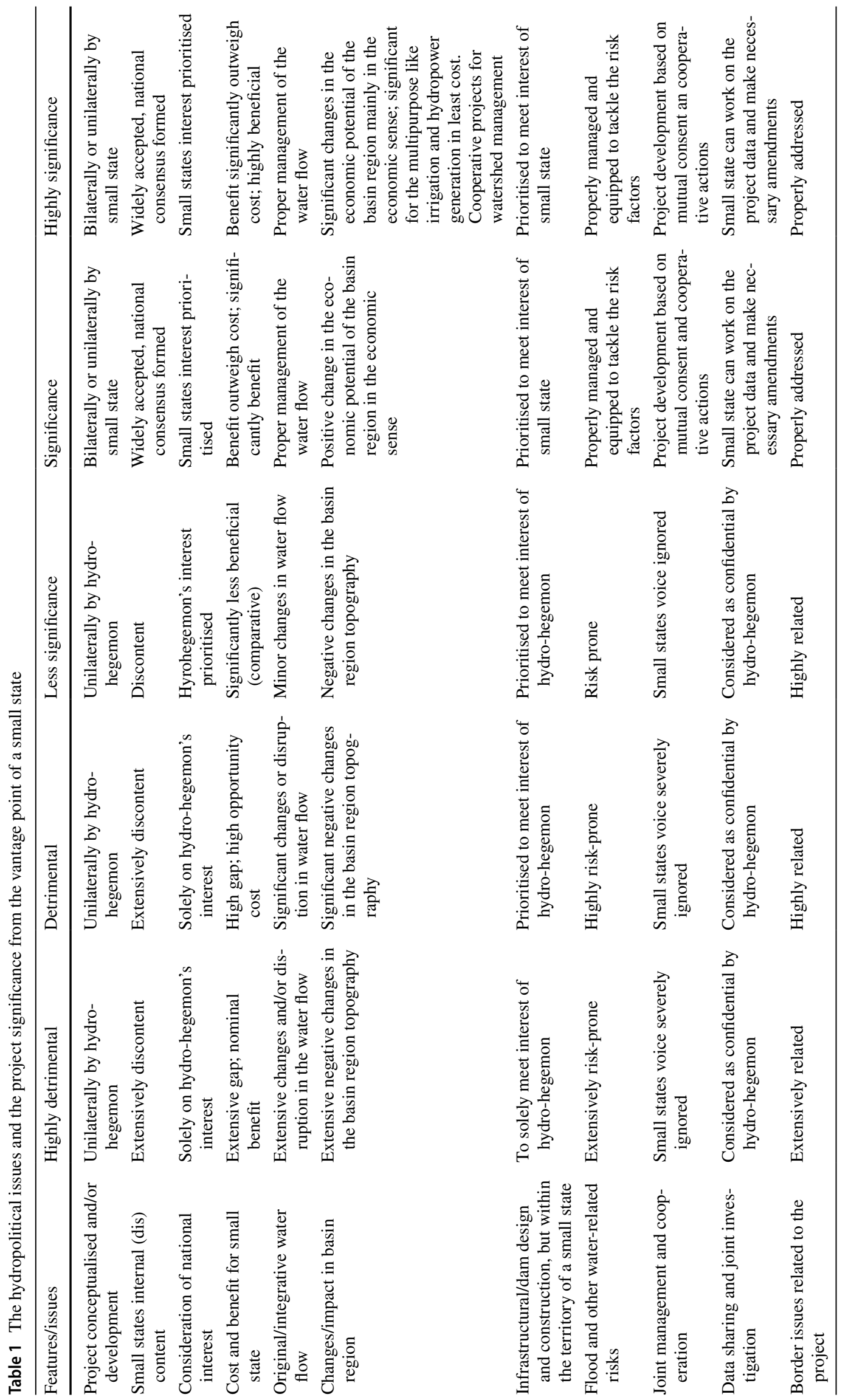


hydropolitical outcome by acknowledging the abreast and undeniable consideration of the origin, action, and outcome. As mentioned earlier, for hydro-hegemon's capability to direct the overall hydropolitical interaction, an unfeigned form of an outcome-either conflict or cooperation that is inclusive of the sensibility of a small state is not something that I intend to get engaged on. Rather, the interaction is problematised when power becomes a determinant factor where a hydro-hegemon is absolved from the responsibility of considering a small state as an active shareholder that is what I intend to focus on. This means that leaving aside the category of highly significance and significance (which are a positive form of interactions), the remaining categories needs a nuanced analysis that not only affect a small state, but also pose a threat to the entire basin ecosystem and the surrounding environment; the former rendering a perfect example of cooperation and the latter, that of a conflictual interaction.

Increasing water scarcity in the developed and emerging economies and the abundance of the resource in the poor and unstable neighbouring states inherently attracts the external interest. With the increasing water scarcity, the economic condition is also subjected to the strategic importance to the volatility of water (Morrisette and Borer 2013) that has made India to secure efficient access and control over water in Nepal. Here, the external interest is linked with the concern for 'control' over the water resources executed based on cost-benefit analysis, relative power, the extent of abundance of the resources and internal domestic condition of the neighbouring weak states. The variation in the (Indian) external interest of meeting the internal water demand (than energy) coupled with the vested political interest and Nepal's interest (mainly) for energy and irrigation has provided the platform for the order that fits the interest of India - whereby Indian interest has been addressing its water 'scarcity' through the (presumed) 'abundant' water of Nepal rather than the regional cooperation (Iyer 2013).

Thus, Nepalese hydropolitical (and related) discontents are the derivatives of the vested political interest-based attitude and practices framed within the existing power relations vis-a-vis India. Nepal's geopolitical setting, water resources, unequal regional water distribution, value, and relative (easy) accessibility are often considered an invitation by the neighbouring states to maintain the geopolitical influence, intervention by pursuing various strategies of water resource control. One of these strategies is to project the rhetoric of development as an (empty) signifier. As in Fig. 3, the external interest is related to the intention of controlling a water resource based on the cost-benefit analysis and relative power.

As mentioned earlier, the river-linking project of India envisions the rivers of Nepal as an integral part of the project, but without consulting Nepal (Pun 2008). As per Cascao (2008, p. 15), India has counted on 'apparent consent' of Nepal, whereby Nepal is unable to express its overt contestation of India's unilateral approach. Realising the significance of water as the source of economic prosperity and strategic imperatives, India has pursued various strategies for controlling the political essence of Nepal for its own security and geopolitical interests. India intends to acquire the control over Nepal's water resources by unilaterally designing the water agreements with Nepal in the form of treaties and agreements, but under the label of development. This, rather than a product of an understanding of the sensibility of Nepal, is to the way of self-serving its interest at the cost of detriment to Nepal. This orientation towards self-professing resonates its purpose of politicisation of the water-issues to buttress its (political) dominance vis-a-vis river basin management. These elements fuse to label India as a hydro-hegemon.

India believes that the bilateral agreements or treaty can be made when neighbour is politically weak and unstable to create confusion, thus deterring the possibility of the weak parties to call the third parties like UN for negotiation (Pant 2012 , p. 73) to assert the hydro-hegemony. Specifically, Indian hegemony can be better understood by the combination of political leadership, powerful negotiation and even lobbying skills, lack of knowledge to Nepalese intellectual, moral and political authorities and considerable capacity of construction of knowledge and discourse.

In this context, SHDMP and UKHP projects ${ }^{13}$ share a common essence, where the interaction between a stronger downstream and weaker upstream is conspicuously visible; forming an inalienable part of the India's river-linking project, but at the expense of the interest of Nepal. The UKHP holds the potential to shape the fate of the Karnali regionone of the least developed regions of Nepal, which is by nature a dam based than Run-of-river (ROR) that could effectively address the power-shortage, water requirement, and the overall development paradigm of Nepal. But these facts have been severely neglected, and to the further dismay, the downsized form of UKHP (900 MW) has led to the abrogation of the potential of 4180 MW of Upper Karnali project, including the projects plans of Nepal (as designed decades ago) like Rajapur, Suryapatuwa irrigation projects, which were coherent to its national interests. All this was made possible by agreeing to a MOU that stipulates that any withdrawal by the upstream would need prior approval of developer, thus privileging India with the 'resource rights' or the 'prior water rights' to the river upstream of the project.

Due to its geographical location, Nepal is obliged to seek Indian consent (lying between Nepal and Bangladesh), for any power purchase affairs with the third country. However, India has been ignorant on Nepal's plan of exporting the 'exporting' the (hydro)-electricity to third countries like

\footnotetext{
13 See Pun (2014) and Shah et al. (2007).
} 
Bangladesh ${ }^{14}$ (even the electricity generated through the UKHP project). As such, India's ignorance on Nepal's issue, including the delayed schedule of UKHP has transformed a bilateral issue (Nepal-India) into a convoluted tri-lateral issue. Nepal's uncertain power-purchase position, further aggravated by the less domestic power demand (Bhattarai 2005) has ultimately prompted the foreign investors to abandon ${ }^{15}$ hydropower projects in Nepal.

Regarding the SHDMP project, the extent of the plausible project impact on Nepal is evident through the general design and nature of the project per se. It is estimated that the dam construction ultimately inundates appx. 11,777 ha of arable plain and displaces at least 10,000 people (and their cultures) in over 80 villages (more details unknown yet) straddled across nine districts, including the repercussive effect of product deficiency and sedimentation flood, and loss of regional biodiversity and ecosystem. Saptakoshi Joint commission office has claimed for the controlling of flood in South-east Nepal and Northern Bihar of India with irrigation facility to a dozens of districts of Eastern and Central tarai region (Linkha 2020, p. 168). But, with the provision for the investment by Nepal as well (Thapa 2019b), the high dam project is highly debatable due to the several repercussive effects to Nepal. ${ }^{16}$ However, on the part of Nepal, there seems a lack of detailed studies ${ }^{17}$ within the frame of costbenefit analysis, its repercussive effects on Nepal, including, but not limited to, product deficiency, sedimentation, flood, and the loss of regional biodiversity and ecosystem. Due

\footnotetext{
${ }^{14}$ India and Nepal had signed Power Trade Agreement in 2014 aimed at easing cross-border electricity flow, which has been stalled due to the lack of policy framework and the reversed position of India. On December 2016, India had issued guidelines on Cross Border Trade of Electricity defining electricity as a "strategic issue" and declared that "only companies that are majority-owned by the Indian government or the domestic private sector are authorized to take part in cross-border electricity trade". But, with the pressure from Nepal and Bhutan, India amended the guidelines in 2018 declaring that "the import and export of electricity between India and neighbouring countries is permitted through mutual agreement between Indian entities and those of the neighbouring country" (Adhikari 2019). Notably, Nepal had signed an agreement with Bangladesh in September 2018 to trade hydropower (esp. regarding the $500 \mathrm{MW}$ out of $900 \mathrm{MW}$ of Upper Karnali project) (ibid.), which has been stalled due to the controversial position of India.

15 For instance, in early 2016, Norwegian energy producer Statkraft discarded plans to develop the $650 \mathrm{MW}$ Tamakoshi III hydropower project in Dolakha (eastern) Nepal. Later, the same project was on the set of agreement between a Nepalese company (TBI holdings) and China's YEIG Intl. and Shanghai investigation, but with the (re) design of downsizing to $200 \mathrm{MW}$ for the reason of lack of the market in July 2019 (Adhikari 2019).

16 See Shah et al. 2007; Dixit 2009; Oza 2014; Shrestha 2016, 2017; Linkha 2020.

${ }^{17}$ For details, see: Oza (2014), Shrestha (2016, 2017) and Linkha (2020).
}

to the limited agricultural lands in the hills and mountains, the inundation of large agricultural land would mean a deficiency in production with the immense change in the imbalance of the surrounding natural environment with disaster with loss of fertile land, ecosystem and biodiversity. More importantly, to address its water issue, Nepal has already designed the Sunkoshi-Kamala Diversion Multipurpose project, as a lifeline project, to irrigate Nepal's Southern (Terai) region enclosed between Saptakoshi and Bagmati rivers (with two power plants) on a year-round basis (Shrestha 2016). If the SHDMP project is implemented, this project gets aborted, leaving Nepal with the less significant Sunkoshi-Marin diversion project. ${ }^{18}$ Furthermore, the international institutions and the World Commission on dams has introduced a guideline for impact assessment and environmental aspects of large dam projects to interrogate the significance of the dam construction (Petheram 2010). Amid the globally increasing discourses on dam construction per se, the dam construction in Nepal, the proposed dam construction in the Siwalik region, which is the most tectonically dynamic zone vulnerable to various forms of slope failure, landslide, and debris flow (Linkha 2020, p. 169), cannot be considered as nugatory. Nonetheless, the issue of local compensation is equally an issue, which India has been ignorant about. ${ }^{19}$

The Indian (hydro)-hegemonic attitude is clearly visible in the case of compensation regarding the SHDMP project, where India asserts that there is no issue with the compensation when the locals (the affected communities) have been demanding 5 million USD as compensation (ANI 2019). It is important to note that it was during the period of political instability in Nepal, when India made the sensitive water resource agreements. During the visit of then Nepali Prime Minister, S.B. Deuba in India in September 2017, when the government in Nepal was unstable, and the national election was at the doorstep, India proposed to prepare the detailed project report (DPR), which Nepal accepted (Thapa 2019a). To add on this, the hydropolitical experience of Nepal with India shows that India has been ignorant to share any plans and details about a project's potential impact on Nepal by claiming it as a wholly Indian project (Gyawali 2013), though constructed in Nepal.

In the case of the upper Karnali project, its MOU stipulates that any withdrawal by the upstream would need prior approval of developer, thus providing the 'prior water rights' to the river upstream of the dam-the resource rights

\footnotetext{
${ }^{18}$ In addition, regarding the project, there are differential claims of both India and Nepal. Though the locales have been demanding 5 million USD as compensation, India claims that the payment has been already made (ANI 2019).

19 The locals have been demanding 5 million USD as compensation, which India claims that the due amount has already been paid (ANI 2019).
} 
privilege provided to India. Further to it, downsizing the project to $900 \mathrm{MW}$ in an outright manner destroys the full hydropower generating capacity of the river, which Nepal could have designed for multipurpose cause (Pun 2014). Due to the project nature, it has been facing severe opposition in Nepal with the severe local discontent and the reported case of bombing of the project office by a splinter Maoist party (Adhikari 2019). However, GMR is still unable to start the construction of the project (even unable to attract investor) and authority of Nepal is still reluctant to revoke the license granted to GMR, rather the license has had been annually renewed (ibid.). The project possesses the capacity to address the power-shortage, water requirement and support the overall development paradigm of Nepal. But Nepal's lack of clear domestic political visioning about the proposed project (as designed by neighbours), conflictual and complex interaction between the state and non-state actors, lack of political will, intellectuality to address the upcoming issues has largely underpinned India to unilaterally design and make agreements for such projects with Nepal.

Amid the "cooperative arrangement imposed by or offered by India (hydro-hegemon), the space available for small states depends on its 'choice' reflecting the consent for the inevitable skewed outcome. Here, Nepal seems to be oblivious of the fact that due to the flow contribution of Nepal's river on the Ganges, the total quantity of static water availability in India without storage dams in Nepal and canals to regulate water during the lean dry months, India's River Linking Project would not function at all, which can transfer surplus water from east to the Ganga to West (Pant 2012, p. 7). In such context, in reference to Table 1, SHDMP can be considered as the 'highly detrimental project', while UKHP as a 'detrimental project', which depict a perfect example of how a 'national water reserve' is transformed to a 'constructed international water basin (CIWB). Here the term 'constructed' has been used in the colloquial sense to depict that Nepal's geopolitical positioning (being upper riparian) as compare to India could have led Nepal with many advantages, but the power asymmetry has played a constitutive role to change the (Nepal's) riparian leverage and led the river basin of Nepal to be bounded within transboundary agreement. Nepal's hydropolitics is unique in the sense that rather than 'obligation', it has been the 'choice' for Nepal to enter in such transboundary agreements. Upon its own choice, Nepal is compelled to face the structural disadvantages and conflictual situation in the transboundary relations (following Elhance 2000; Kehl 2010).

The precedence of Indian interest over the interest of Nepal with the focus on 'exploitation' and 'control' of Nepal's (untapped) water resource rather than the 'use' and 'share', has left Nepal to experience the negative outcome of the project with the reduced bargaining power. In the words of Adhikari (2019), India's motive of controlling Nepal's resource and 'micro-manage' Nepal's internal politics indicates Nepal being treated as 'buffer' than a hydropolitical trading partner. In the two projects, despite the capability of developing and constructing the project by itself, without affecting and antagonising India, Nepal instead has entered or is in the process of entering in the transboundary agreements. Here rather than 'sharing' it has been the matter of 'willingness' as determined by the complex factor of nationalism and internal political context, that has been internally driven by the dilemma of abundance and domestic needs of Nepal. Within the dilemma of persisting claim of inequitable distribution of water resources, the geopolitical complexities, geopolitical nature of basin, internal politics and external interest have underpinned the hydropolitical configuration of Nepal vis-a-vis India and also sustained the Indian political hegemony in Nepal. India's unilateral and hegemonic approach in the transboundary water agreements have stirred frequent controversies in Nepal that are linked to the issues of sovereignty, nationalism and autonomous status of Nepal. Amid the resource geopolitics of Nepal being dominated by water, Nepal's water resource is gaining increasing attention from India, for which it is keen to use any strategies of 'resource control' (except the military might) over the water resources of Nepal that can be termed as 'neo-colonial' way of resource subjection. The challenge for Nepal has been to resist and counter the hydro-hegemony of India that illustrates the neocolonial practices. In the next section, I intend to outline the substantial resistance of Nepal against the hydro-hegemony of India dependent on the factors of the notion of knowledge construction and resource nationalism.

\section{Knowledge (re)-construction and resource nationalism as response to hydro-hegemony and its limitations}

The discourses on power remain incomplete without the meaningful consideration of resistance attributed to the heterogeneity engendered in the various interactions. As scholars like Gill (2008) and Gopal (2019) point out that resistance being an attribute of power cannot be isolated as having its self-existence. Power and resistance both are bi-polar in nature; a hegemon incessantly exerts power concomitantly resisting the power (of small extent) of a non-hegemon, whereas the latter, apart from resisting the power of the former, also exerts power to incline the system (of interaction) towards its interests. Thus, the strategies of resistance and counter-hydro-hegemony can nevertheless be revealed and operationalised. The counter-hegemonic strategy is based on three pillars: challenging status quo, contesting hegemonic legitimacy and building creative form of resistance (Cascao 2008). I allude that the counter hydro-hegemony needs to 
Fig. 4 Hydropolitical field (Source: Author)

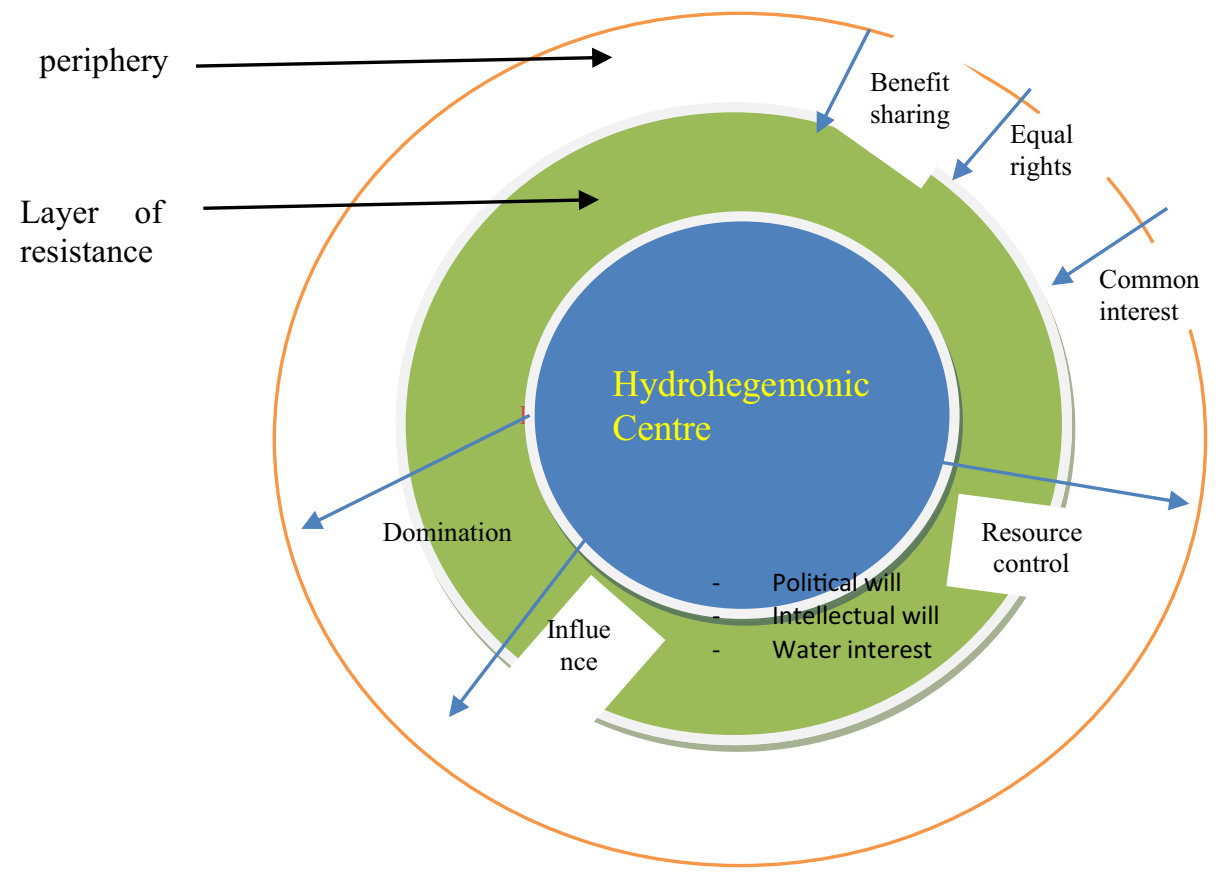

be more than just challenging the status quo that needs to focus on the creation of alternatives basically change in the basin regime towards the maintenance of integrative water flow with more focus on 'use' and 'management' rather than 'exploitation' and 'control' of the water resources. The existing hydropolitical discourses attributes to the pedagogical formation that is framed within a specific form of the knowledge produced with the facilitation of the power over ideas.

\section{Knowledge (re)-construction}

The power over ideas is the most effective and common form of power that exists through discourse, moving from the conscious world of bargaining to the subconscious world of predetermined outcomes (Zeitoun et al. 2010, p. 164). In this context, the meaningful inquiry to the hegemonic activity implies moving away from the tendency to privilege hegemony as a 'self-correcting and maintaining device' to allow space for the weaker states regarding their resource subjection. Sermonising that the knowledge gap plays a decisive role in permitting the hegemon to reinforce power in policy and decision-making, ${ }^{20}$ the counter-hegemonic strategy infers the realisation, construction, interpretation, and dissemination of the discourses that challenge the hegemonic ideas and knowledge.

Against the backdrop of the prevailing neo-colonial form of resource subjection, the notion of 'centre' and 'periphery'

$\overline{{ }^{20} \text { See Cascao }}$ (2008, p. 25). is remarkably applicable in the hydropolitical interaction of Nepal with India, where the former is positioned at the periphery by the latter. I have termed the constitution of such hydropolitical interaction with the centre and periphery as the 'hydropolitical field'. Here the centre, as compared to the periphery, is characterised by the possession of a disproportionate level of political and intellectual influence and agency that is keen to exert the influence to seek control over the resource present within (or in transboundary water basin) the weaker states. Whereas the periphery is characterised by its collective silence (in some cases) in the hydropolitical issues that is keen to maintain the norms of benefit sharing, equal rights, common-interest, and integrative flow of water.

The centre possesses a resilient and stubborn immunity that consolidates to form a 'layer of resistance' that effectively safeguards it from the peripheral resistance and sustains the political and intellectual hegemony and the resource subjection. In other words, the hydropolitical fieldrather than a static interaction-posits an incessant interaction between the centre and periphery characterised by the continuous radiation of the influence/domination from the centre that is subject to the resistance from the periphery; a dialogic form of interaction. The phenomenon continues till 'critical limit' is achieved, beyond where the status quo is changed thus leading to either the alteration of the hydropolitical interaction or termination of the interaction, which in some cases risks of affecting the interacting states bilateral relationships.

Taking an account of Fig. 4, the peripheral locality of Nepal is subject to the multifaceted factors that meticulously includes the external (India) and the internal or endogenous 
factors. With the discussion of Indian hegemony, now it is relevant to discuss how well Nepal acknowledges or internalises its own hydropolitical formation. The unfolded fact is that Nepal's thwarted and perceived lack of agency is largely a product of a produced knowledge that professed the 'abundance of water in Nepal', which later became the defining narrative or factor of the hydropolitical interaction of Nepal.

In the case of Nepal, the substantial resistance is dependent on the various factors, like the notion of resource nationalism and (political, campaigner and intellectual) will the collective of which hold the potential to resist the hydrohegemonic influence. Under the condition of the higher level of the 'peripheral' resistance than the 'central' power, then the weaker states resistance can be decisive. However, in the two cases, it is apparent that Nepal's 'resistance' do not overrun the Indian 'power'. As in the case of UKHP project, subject to the abrogation of the agreement terms by GMR, the license of GMR could have been revoked, which is not the case, rather, the contract is renewed annually. Likewise, in the case of SHDMP project, Nepal could have stood firm on the voice of its national interest and declined the Indian proposal for making the final agreement of the project. Thus, these two projects depict Nepal's lack of agency in resisting the prevailing Indian hydro-hegemonic influence rather, it has internalised the Indian will that is largely favoured by the myth of abundance that necessitates the knowledge (re) construction required both internally (in Nepal) and externally.

\section{Domestic needs of Nepal and myth of abundance}

The 'myth of abundance' has been enrooted in the hydropolitical psyche of Nepal since the study of Shrestha (1966), cadastre of potential water power resources of less studied high mountainous regions, with special reference to Nepal. In the course of time, this later germinated three schools of thoughts that infused the norms of water abundance, hydropower potential, energy production, national development, foreign interest, and export: (1) water resource is not subject to any foreign agreement, for the electricity generated is not for the purpose of export; (2) due the inverse relation between its water (and hydropower potential) abundance and (weak) political, technical, and financial position, the electricity export needs to be prioritised; (3) Nepal holds the capability to develop some hydroelectric projects; thus, the surplus electricity can be exported. Here, the first school of thought seems to be ineffectual; however, the third holds the potential of addressing the notion of conservation, utility, management aspect of the water resource. But, more importantly, the second school of thought carries an array of interwoven complexities, which is the driving factor of the hydropolitical realm, including the planning and development, of Nepal that has reified the illusive myth of getting rich by exporting electricity. ${ }^{21}$

Ironically, such an attitude conveniently perceives water as a tool or commodity subject to exportation, negating the equation between the notion of domestic needs and production potential that could address the balance among the water abundance, national industrialisation and development, upstream-downstream linkages and the hydropower export. Though the studies (as stated earlier) postulate the hydropower potential of Nepal as 83,000 MW, but the issue aroused within the knowledge gap between the 'popularised' and the 'real' potential. In fact, out of the theoretical but 'popularised' $83,000 \mathrm{MW}$ hydroelectricity potential, only $42,000 \mathrm{MW}$ is technically feasible in Nepal. To add on this, if the high dam storage projects are kept aside by considering only run-of river (ROR) and small storage schemes and projects, the potential is further reduced to 20,000 MW; At $90 \%$ exceedance, the hydropower potential is even less to just 12,000 MW (Shrestha 2016, 2017).

Against this backdrop, Nepal's current hydropower generation tells a different story. Till now, Nepal has hardly been able to harness even $1 \%$ of its total potential, whereby it is still dependent on India to import almost half of its electricity demand of $1480 \mathrm{MW}$. It is projected that within the beginning of 2022, Nepal will be able to generate $2300 \mathrm{MW}$; however, the demand supply trajectory indicates that the demand will not exceed $1500 \mathrm{MW}$, thus leaving the electricity spillage of about $800 \mathrm{MW} \cdot{ }^{23}$ Leaving aside this simplistic and horizontal form of projection, the consideration of the increased level of economic development and the pursuance the wider developmental goals-hydroelectricity being the viable energy source of Nepal illustrates a different figure. According to this, Nepal would be able to consume around $15,000 \mathrm{MW}$ in the next 25 years and referring to the earlier data of the (hydro)-electricity potential of $12,000^{24}$; the overlap between demand and supply can be significantly located.

This transforms the affirmation of the abundance of water resources (as mainly viewed through the lens of hydropower generation) towards an elusive myth. The irony for Nepal has been that such myth has percolated the political, ${ }^{25}$

\footnotetext{
${ }^{21}$ There has been a persistent and rampant rhetoric about the 'abundant' hydropower potential of Nepal whereby 'facing poverty with hydropower potential' has been the political truism (Dixit and Gyawali 2010; Gyawali 2013).

${ }^{22}$ For details see Bhattarai (2019); it is not an age-old story that Nepal had faced the electricity shortage of up-to $18 \mathrm{~h}$ a day.

23 This amounts to the loss of around US $\$ 150$ million in the present day rate of NEA.

${ }^{24}$ The Nepal government's white paper on the energy, water resources and irrigation sector aims to increase the production capacity to $15,000 \mathrm{MW}$. For details, see Bhattarai (2019).

25 During 1990s, Former prime minister of Nepal, Mr. G. P. Koirala's in a statement had referred as "no more than waste water" (Pant 2012, p. 67).
} 
intellectual, and social psyche that incentivises the free and unrestricted exploitation of the water resource. This has left deep multilateral implications in the overall (hydro) project designing, licensing, overall-hydropower development strategy of Nepal, and consequently paved the way for external involvement or intervention. Such discourses that feed to the rampant (external) commodification of water as an infinite resource have ultimately left Nepal devoid of cheap and efficient energy generation. As Shrestha (2017, p. 4) affirms that in the race of mass commodification, the larger projects are prioritised that require the external assistance (in terms of technical expertise, large capital) undermining the practices of self-study, self-finance, self-construction, and self-reliance (learning by doing).

Moreover, as mentioned earlier, there are clear indications that India is less concerned about the electricity trade of Nepal, including the agreements on the cross-border electricity guideline and conduct of business rule (CBR). On its part, Nepal (according to the Indo-Nepal construction agreement) has already completed the $400 \mathrm{kV}$. DhalevarMujaffarpur transboundary transmission line in 2012 followed by the electricity trade agreement 2014 with India. But the further collaborative projects have been deliberately delayed or stalled by India, including the concept of 'energy banking ${ }^{26}$ for the purpose of exporting the energy during monsoon and import during the dry season, and the selection of the nodal agency. To add further, Nepal's cost of electricity is expensive than that of India and Bangladesh, which are adopting efficient and cost-effective renewable energy generation technologies (Bhattarai 2019). Besides this, the cost of transboundary electricity transmission, increased rate of internal pilferage, high cost of electricity have repelled the external investment.

Contrary to these empirical evidence, Nepal is in the race to exploit its water resources within the imaginary field of 'abundance of water resources aggravated by its intention of cutting off the takeover of the hydroelectricity generated by Bhutan, but by ceding its riverine rights. The case of UKHP and SHDMP share a common theme that India has been succeeded to assert the principle of "existing prior consumptive

\footnotetext{
${ }^{26}$ In Nepal, there is low demand during the winter season and high demand in the dry season, whereas the case is quite opposite for India. This concept could be appropriate for Nepal to sell at a high price during winter and import at a cheaper price during the wet season. For details, see Kumar (2020). Electricity in monsoon and dry season, online available at: https://www.himalkhabar.com/news/ 122174?fbclid=IwAR08f7DCx4OwOqAEK8FnkZI2VC8eKK1EH Bmy0obKNiF6s-xG1Js-YradE1M\%20internal\%20status\%20vs (In Nep.) $(15 / 02 / 2021)$.
}

use', fixating Nepal's right over such bodies in dismay. This is illustrated through the data that till now, Nepal electricity authority ${ }^{27}$ has already doled out $5157 \mathrm{MW}(85.6 \%$ of total license) of the hydropower license to Indian companies; the result is that Nepal is devoid of any cost-effective hydropower project at hand for immediate development (Shrestha 2016, p. 14). This has left Nepal on the verge of losing the grip from its own water resources and fixate itself as a 'Rentier state' by renting its resource to external clients. Furthermore, it has created a frayed juncture among the utility, management and conservation of the water resources and instead rationalised the presence of the hydro-hegemons.

Scholars like Hanasz (2014, p. 97) have admired the presence of hydro-hegemon as an assurance for the regional stability and as a patronage for the weaker states. In line with this, some scholars like Butler (2016) and Chellaney (2013) have rationalised the presence of the external actors for Nepal's weak economic and proficiency status to develop and manage the water resource projects like hydro-power generation and flood control. Such assertion is subject to repudiation in the case of UKHP project. Intriguingly, the project agreement was made with $\mathrm{GMR}^{28}$ in a way, where the subsidies and privileges offered by Nepal gets equal to the total project construction cost (around $\$ 700$ million) (Pun 2014). More importantly, the agreement was made in a way that explicitly violated the article $156^{29}$ of the interim constitution of Nepal (2007) that necessitated for the parliament ratification. Interestingly, despite such privileges, GMR is unable to set up the construction date and attract the investor, for which Nepal is renewing the annual license. In this context, the rationalisation of the presence of India is an excuse for self-congratulation. Thus, for India, its involvement in the hydropolitical interactions with Nepal manifests its desire to assert various forms of power-related resource control strategies to secure their geopolitical interests, intensifying the political relation within an already fragile condition.

\footnotetext{
27 Operated under the ministry of Energy, Nepal Electricity Authority, created on August 16, 1985 under Nepal electricity act, is the government body responsible for generating, transmitting and distributing adequate, reliable and affordable power in Nepal.

${ }^{28}$ Shrestha (2017, p. 4) has even cited the UKHP agreement with GMR as 'suicidal' for Nepal.

29 "Article 156, Ratification of, accession to, acceptance of or approval of, treaties or agreements: .......(2) Any law to be made pursuant ......shall, inter alia, require that the ratification of, accession to, acceptance of, or approval of, treaties or agreements on the following subjects must be made, by a two-thirds majority of the total number of the then members of the Legislature-Parliament........ (d) Natural resources, and the distribution of their uses". (Source; Interim Constitution of Nepal 2007, available: https://www.wipo.int/edocs/ lexdocs/laws/en/np/np006en.pdf (07/01/2020).
} 
Thus, the pervasive myth of water abundance in Nepal is a product of the lack of an honest evaluation between the 'popularised potential' and the 'real potential' of the water resources of Nepal, and thus subject to refutation, that has instead paved the way for India to exert its hegemony in the intellectual, economic, and political formation. The hydro-hegemonic setting is configured in a way that unilaterally serves the will and interest of a hydro-hegemon at the expense a weaker entity. As in the imperial settings, where the rule of game used to be set by the colonizer (Zeitoun et al. 2010, p. 164), India has unilaterally set the agendas that is often internalised by Nepal. The (often unconditional) acceptance of the hegemonic ideas and order as natural by Nepal signifies that its implicit (or explicit) consent for the outcome is assured at some point between fully conscious bargaining for altering the established order and its completely absorbed acceptance.

Evidently, here the problem is India's tendency to negate Nepal's sensibility and Nepal's lack of real momentum for capitalising its water resources upon its national interest. Nepal's lack of converting the resource opportunity ${ }^{30}$ for its national benefit has led the neighbours (mainly India) to include the security imperative within the hydropolitical interaction in the name of the cooperation. ${ }^{31}$ Thus, the rhetoric of water resource development, rather than abstraction as derived from emancipation that is a homogenous intellectual formation, is real and constructed to serve the neo-colonial adventure of India advocating its centrality. Referring to Fig. 4, within the hydropolitical realm, the political and intellectual production of knowledge is the product of the existing power disparity and the extent of internalisation, which feeds the hydro-hegemon's interests concomitantly peripheralising the weaker; thus, it is subject to critical engagement. There is a fear that Nepal is on its way towards losing both the cheaper (hydro) energy source and the attractive foreign investment to fulfil its ravishing dream of 'economic development by electricity export'. This necessitates for the ruling planners, politicians, decision makers and public to unlearn and deconstruct the concept of abundance of water potential in Nepal to resist the hydrohegemonic attitude of India and adhere to the notion of the resource nationalism.

\footnotetext{
30 Zeitoun (2007 in Mirumachi and Allan 2007) has considered 'Securitized' and 'opportunitized' as the two sides of a coin, whereby the former is related to the threat that rationalises emergency measures. On the other hand, the latter relates to an opportunity for improving a condition that demands emergency measures.

31 During the Koshi flood in 2008 that claimed the lives of hundreds and displacement of thousands, to facilitate Nepal, India had set up a field office in Biratnagar, which was unilaterally upgraded as a Consulate General office (that was later closed in May 2018 after pursuance of Nepal) (Shah 2018).
}

\section{Response to hydro-hegemony: resource nationalism}

As the decision at one level affects another basin resource, the transboundary water system lacks the integrated basin or aquifer management system for which the national sovereignty comes in the forefront (Waslekar 2011). A nationstate's presumed right over the ownership and control of the water resources lying within its political jurisdiction subsequently implicates the significance of the resource nationalism as one of the viable strategic practices available for a small state for countering (hydro)-hegemony. Resource nationalism is the tendency of people or government to proclaim the control over natural resources within their territory, shifting the political and economic control of the resource from foreign/private interests to domestic and state-controlled (Bremmer and Johnston 2009).

As mentioned earlier, due to the Indian keenness to engage and Nepal's weak stance have led to the hydropolitical interactions that negate the collective repository of the norms of exploitation, conservation, and management. Here the issue is about the management, for which Mollinga (2008, p. 8) affirms that the concern for theme of (good) governance ${ }^{32}$ has brought politics into the mainstream water resources, which is organised in regionally and sector-wise defined clusters rather than a dispersed field. The appropriation of water is an environmental and political issue, where the politics of water also relates to the issues of resource management that encases the holistic sense of the ecosystem of watershed management, including the issues surrounding scarcity, the equitable distribution, and the maintenance of the integrative water flow minimising the norms of exploitation and control. ${ }^{33}$ That the direct relationship of the waterrelated projects (like irrigation and mega-hydropower) with the international relations, the rationalising the issue of the water sharing, use, utility and management carries a special significance within the hydropolitical complexes of Nepal. ${ }^{34}$

Remarkably, amid the hegemonic attitude of India, Nepal has progressively ceded its rights over its natural resources. After the democratic movement in 1990, the interim Prime Minister of Nepal, Mr. K.P. Bhattarai (from Nepali congress party) paid a visit to India on June 10, 1990, when PM Bhattarai, together with his Indian counterpart Mr. V.P. Singh released a joint statement that included a phrase 'common rivers' on account of the river development of Nepal. This

\footnotetext{
32 As Mollinga (2008, p. 8) affirms that discussing about governance (good or bad), and related ideas like accountability, transparency and legitimacy, it is important to acknowledge that such processes and relations have political dimensions (Mollinga 2008, p. 8).

${ }^{33}$ For details, see Renner (2009, p. 2) and Rai et al. (2017, p. 791).

${ }^{34}$ See Iyer (2013) and Lama (2019).
} 
was labelled as 'selling out' the resources of Nepal to India and thus, gained a wide public outrage in Nepal and an agenda for the 1991 general election (Shrestha 2017). Evidently, for Nepal, such depiction of the 'common resource' poses the threat of paving the way for the 'external exploitation' of its water resources, subsequently ceding its rights from using its resources and leading it to experience the 'tragedy of commons ${ }^{35}$ as conceptualised by Hardin (1968).

The annals of Nepal's hydropolitical interaction with India remarkably illustrates the significant change in the contour of the hydropolitical interaction mainly after 1990, when Nepal's increasing interaction concomitantly left Nepal with a decreasing index of the bargaining power and stance in terms of its national interests. This illustrates the direct bearing of the internal political condition with the hydropolitical interaction of Nepal, and a calculative strategy as employed by India upon Nepal. With the various water resource agreements made by Nepal with India, until the period of UKHP, India was able to place its interest in a unilateral manner, which is on the verge of a tendency to seek the sole Indian interest at the cost of interest of Nepal until the time of en route SKDMP.

Hence, Nepal has not only debilitated its (firm) stance on the affairs of its national interests, but also been vulnerable to any form of resource exploitation and geopolitical vulnerability. This is an elucidation of the appreciating hydropolitics within the frame of high politics, but with the weak nationalist sentiment of Nepal. The territorialized system of state power can be largely unsettled or unstable in certain cases as in the transboundary water flow that allow biophysical permeability to geopolitical border, restricting the privileges of state to assert permanent sovereignty exercise over its hydrological resources ${ }^{36}$ which denotes a certain form of the state-nature relation referred as 'Fluid sovereignty' (Mason and Khawlies 2016, p. 1347), which is applicable in the case of Nepal as well.

Nepal's negligence on the prioritization of the self-management and utilisation of its resources has led to several repercussions: its tendency to seek the neighbours dependency has created the platform for the external resource exploitation; restricted the autonomous rights to manage (and utilise) its resources; and has escalated its geopolitical vulnerability with increasing neighbour's interest on the

\footnotetext{
35 The concept of 'Tragedy of the commons', was made popular by ecologist Hardin (1968), using the analogy of using the common field by ranchers for grazing their animals. Lack of collective thinking and continuation of grazing the livestock by each rancher will ultimately lead to the condition when no ranchers become able to graze due to overconsumption of the grazing land. This scenario is often used for indicating the condition of overconsumption of natural resources like water.

36 See also Iyer (2013) and Lama (2019).
}

resources. This has led to the decreased bargaining power of Nepal with the disadvantaged position in the present and future transboundary water project. To add on this, Nepal's position on the projects like Upper Karnali and enroute Saptakoshi high dam project are suggesting Nepal's weakening grip on its own natural resources. As per Auty (1993 in Tipchanta 2012), the invitation for the foreign actors on its resources in turn poses the risk of the likelihood of resource curse theory by political and economic means. Such resource degeneration not only exacerbates the internal political, social and cultural aspects of Nepal but also has helped to invite corruption, conflict and neo-colonialism. Nepal has even plunged in the dilemma of conservation, development and resource nationalism. Recognising the significance of UKHP, Nepal needs to seek the way for the self-construction of the project, whereas recognising the plausible detrimental impact of SHDMP project, Nepal needs to decline the Indian proposal. Here the configuration of hydropolitics has not been the sole result of power-play, but when the power-asymmetry gets compounded with the domestic political instability (of a small state), then hydropolitical outcome leans towards the direction of hydro-hegemony. Thus, hydro-hegemony rather than being the 'natural' consequence of power asymmetry can also be 'constructed' and be 'bestowed' up on.

As in the case of UKHP, Butler (2016) has noticed the extent of persuasion of Indian active lobbies for the renewal of the project with GMR; this can be related to Nepal's hesitancy to revoke the license of GMR. Moreover, in the case of SHDMP, ${ }^{37}$ instead of making an honest and nationalistic assessment of the project impact, including the proper utilisation of the water resources, Nepal tends to involve India posing the risk of experiencing the 'resource curse ${ }^{38}$, by political and economic means. These examples direct to the way the interrelationship between the internal political status and degree of the firm stance in the affairs of national interest that favours the successful execution of the notion of the resource nationalism to act against any form of hydrohegemony effectively. Referring to Fig. 4, Nepal has kept itself aloof from exerting the high amount of the resistance, which could effectively reach the critical or threshold limit (and even traverse) against the Indian influence and domination in its water resources. The high level of political, social, cultural and economic interaction with Nepal, has provided the leverage to India that has enabled it to remain immune

\footnotetext{
37 For this, Iyer (2013) has suggested Nepal to avoid the dam related projects and scrapping the controversial old treaties.

38 Resource curse theory (Auty 1993 in Tipchanta 2012) refers to the paradox that, with the abundance of natural resources (like fossil fuels and specific minerals), some countries have unexpectedly less economic growth, less democracy and worse development outcome as compare to the countries with lesser resources.
} 
against any resistance from Nepal, through the construction of a stronger layer of resistance, to establish itself as a (sole) benefactor, subsequently negating the norms of benefit sharing, equal rights, and the integrative water flow. As such, addressing the national interest without marginalising the social, environmental, and developmental norms have been the challenge for Nepal.

By exemplifying the distant evolving (or devolving) hydropolitical reality, such resource degeneration not only exacerbates the internal political, social and cultural aspects of Nepal, but also has helped to feed the notion of corruption, conflict and neo-colonialism. Regrettably, the hydrohegemony of India has created a negative sentiment towards India in Nepal that has hindered harmonious discussion on common hydropolitical interests. Here the various factors like lack of internal political consensus, lack of knowledge, controversial PPA, obligation of tax or pay ${ }^{39}$ has weakened Nepal's resource nationalism and thus the effective resistance of the hydro-hegemony of India. In this context, a crucial part of Nepal's undeclared counter-hegemony strategy includes the mechanisms for the construction, collection, interpretation and dissemination of the knowledge that could improve its international status, negotiation, decision-making process and largely favour for the optimal utilisation of its resources including social, environmental, economic and political sustainable policies with the notion of resource nationalism (Figs. 3, 4).

\section{Conclusion}

With the growing concern about future access to and control over water resources, globally water security is emerging as a compelling resource-based challenge with the increasing population and rising demand (Kaniaru 2015, p. 381). Nepal's strategic setting, natural resources, unequal distribution of water in the region, value, and relative ease of access motivate the external parties to influence, intervene, and behave in a hegemonic manner to protect their vital interest (Kehl 2010).

As such, Nepalese hydropolitical issues are mainly derived from vested political interest-based behaviour and the actions framed within the special power relations of India and Nepal. Water development has often been a stratagem for India to secure geopolitical interests and control regional political powers in this remote area. But for Nepal, the problem is seemingly embedded within the proper management, utilisation and governance of the

\footnotetext{
39 While making the agreement with foreign companies, Nepal has to purchase the energy produced or pay if not purchased, referred as 'Tax or pay'
}

water resource than the availability. Through examination of the Upper-Karnali hydropower project and Saptakoshi high dam project, this paper reveals that there is a risk for Nepal that those water projects hold the potentiality to be used as a tempting proposition to strengthen Indian interest and influence. Therefore, Nepal needs to orient towards the sustainable water resource development with due attention given to the nationalistic approach than the regime centric approach to shield itself from any resource-related intervention, tactics and strategies employed by India. Recognising the significance of UKHP, Nepal needs to seek the way for the self-construction of the project. Whereas, appreciating the plausible detrimental impact of SHDMP project, Nepal needs to reconsider before making any further agreements with India. Thus, with its limited manoeuvrability, Nepal has sought to address the discontent and develop resistance against any Indian hegemonic interaction to secure better opportunities for developing transboundary water resource projects.

Open Access This article is licensed under a Creative Commons Attribution 4.0 International License, which permits use, sharing, adaptation, distribution and reproduction in any medium or format, as long as you give appropriate credit to the original author(s) and the source, provide a link to the Creative Commons licence, and indicate if changes were made. The images or other third party material in this article are included in the article's Creative Commons licence, unless indicated otherwise in a credit line to the material. If material is not included in the article's Creative Commons licence and your intended use is not permitted by statutory regulation or exceeds the permitted use, you will need to obtain permission directly from the copyright holder. To view a copy of this licence, visit http://creativecommons.org/licenses/by/4.0/.

\section{References}

Adhikari D (2019) Nepal power export plans in doubt as India reviews options. Nikkei Asia Review. https://asia.nikkei.com/Politics/Inter national-relations/Nepal-power-export-plans-in-doubt-as-Indiareviews-options. Accessed 1 July 2020

ANINews (2019) Work on Sapta Kosi high dam on hold due to disagreement between India and Nepal. https://www.aninews.in/news/ world/asia/work-on-sapta-kosi-high-dam-on-hold-due-to-disag reement-between-india-and-nepal20190716233309/. Accessed 14 Aug 2020

Barnaby W (2009) Do nations go to war over water? Nature 458:282-283

Bhattarai R (2005) Geopolitics of Nepal and international responses to conflict transformation. Friends for Peace, Kathmandu

Bhattarai D (2019) Who will buy Nepal's hydropower? Third pole. https://www.thethirdpole.net/en/2019/04/09/opinion-who-willbuy-nepals-hydropower/. Accessed 1 July 2020

Bremmer I, Johnston R (2009) The rise and fall of resource nationalism. Survival 51(2):149-158

Butler CJ (2016) Knowledge, nature and nationalism: the Upper Karnali Dam in Nepal. Dissertation, University of California Santa Cruz

Cascão AE (2008) Ethiopia-challenges to Egyptian hegemony in the Nile Basin. Water Policy 10:13-28 
Cascão AE (2009) Changing power relations in the Nile River Basin: unilateralism vs. cooperation. Water Altern 2(2):245-268

Chellaney B (2013) Water: Asia's new battleground. Georgetown University Press, Washington

Dinar S (2002) Water, security, conflict, and cooperation. SAIS Rev XXII 2:229-253

Dixit A (2009) Kosi embankment breach in Nepal: need for a paradigm shift in responding to floods. Econ Polit Wkly 44:70-78

Dixit A, Gyawali D (2010) Nepal's constructive dialogue on dams and development. Water Altern 3:106-123

Doty RL (1996) Imperial encounters: the politics of representation in north-south relations. University of Minnesota Press, Minnesota

Elhance AP (2000) Hydropolitics: grounds for despair, reasons for hope. Int Negot 5:201-222

Frohlich CJ (2012) Water: reason for conflict or catalyst for peace? The case of the Middle East. https://www.cairn.info/revue-1europe-en-formation-2012-3-page-139.htm. Accessed 14 Nov 2019

Gibbs LM (2009) Just add water: colonisation, water governance, and the Australian inland. Environ Plan 41:2964-2983

Gill S (2008) Power and resistance in the New World order. Palgrave MacMillan, New York

Gleick P (1993) Water and conflict. Int Secur 18(9):79-112

Gopal P (2019) Insurgent empire: anticolonial resistance and British dissent. Verso, London

Gupta KR (2008) The India Nepal treaty. In: Water crisis in India. Atlantic Publishers and Dist, New Delhi

Gyawali D (2013) Reflecting on the chasm between water punditry and water politics. Water Altern 6(2):177-194

Hanasz P (2014) Power flows hydro-hegemony and water conflicts in South Asia. Secur Chall 10(3):95-112

Hardin G (1968) Tragedy of the commons. The library of economics and liberty. https://www.econlib.org/library/Enc/Tragedyoft heCommons.html. Accessed 1 Dec 2019

Iyer RR (2013) Water politics. Nepal energy forum. http://www.nepal energyforum.com/water-politics/. Accessed 16 Jan 2020

Jägerskog A, Zeitoun M (2009) Getting transboundary water right: theory and practice for effective cooperation report nr. 25. SIWI, Stockholm

Kaniaru W (2015) From scarcity to security: water as a potential factor for conflict and cooperation in Southern Africa. S Afr J Int Aff 22(3):381-396

Kehl JR (2010) Oil, water, blood and diamonds: international intervention in resource disputes. Int Negot 15:391-412

Kumar R (2020) Power cuts are back in Nepal. Nepali Times. https:// www.nepalitimes.com/latest/power-cuts-are-back-in-nepal/. Accessed 2 Apr 2021

Lama N (2019) Re-negotiating the Mahakali Treaty in the changing geopolitics of Nepal. Int J Sci Res Publ 9(1):417-420

Linkha TR (2020) The Saptakoshi high dam project and its bio-physical consequences in the Arun river basin Article. Geogr J Nepal 13:167-184

Lufkan B (2017) Why hydropolitics will shape the 21st century? https://www.bbc.com/future/article/20170615-why-hydro-polit ics-will-shape-the-21st-century. Accessed 21 Dec 2019

Mahlakeng MK (2019) A theoretical analysis of hydropolitics. World Aff J Intern Issues 23(4):36-57

Mason M, Khawlie M (2016) Fluid sovereignty: state-nature relations in the Hasbani Basin, Southern Lebanon. Ann Am Assoc Geogr 106:1344-1359

Mirumachi N (2015) Transboundary water politics in the developing world. Routledge, London

Mirumachi N, Allan JA (2007) Revisiting transboundary water governance: power, conflict cooperation and the political economy. In: Proceedings from CAIWA international conference on adaptive and integrated water management: coping with scarcity. Basel, Switzerland, p 1215

Mollinga PP (2008) Water, politics and development: framing a political sociology of water resource management. Water Altern 1:7-23

Morrissette J, Borer D (2013) Where oil and water mix: environmental scarcity and future conflict in the middle east and North Africa. http://www.iraqicivilsociety.org/wp-content/uploads/2013/02/ borer1.pdf. Accessed 15 Dec 2019

Nagheeby M, Warner J (2018) The geopolitical overlay of the hydropolitics of the Harirud River Basin. Int Environ Agreem 18:39-860

NESS (2012) Environmental impact assessment study of Upper Karnali hydropower project (UKHPP), $900 \mathrm{MW}$

Oza J (2014) resisting for the river: local struggle against the proposed Saptakoshi River Dam. Dissertation, Wesleyan University Environmental Studies

Pant SD (2012) Water politics on Nepal's freshwater. Institute for Rural development (SIRUD), Kathmandu

Petheram L (2010) Dam it?: Hydropolitics in the changing political context of Nepal. Dissertation, University of Otago

Pun SB (2008) Paraguay, Bhutan and Nepal: landlocked but hydropower rich, cases of the lame duck, flying goose and sitting duck. Ratna publication, Kathmandu

Pun SB (2014) Forfeiting 4,180 MW Upper Karnali storage for 900 MW Upper-Karnali. Ratna publication, Kathmandu

Rai SP, Wolf AT, Sharma N (2017) Hydropolitics and hydropolitical dynamics between India and Nepal: an event-based study. Water Policy 19:791-819

Renner M (2009) Water challenges in Central-South Asia. Noref Policy Brief. 4. The Norwegian Peacebuilding Centre

Selby J (2003) Dressing up domination as 'cooperation': the case of the Israeli Palestinian water relations. Rev Int Stud 29:121-138

Shah DN (2018) India closes its field office in Biratnagar. The Kathmandu Post. https://kathmandupost.com/national/2018/08/02/ india-closes-its-field-office-in-biratnagar. Accessed 13 Nov 2019

Shah T, Singhe UA, McCornick PG (2007) India's river-linking project: the state of the debate. IWMI-CPWF draft Project on Strategic Analyses of India's National River-Linking Project, Colombo, Sri Lanka. International Water Management Institute

Shaurabh (2012) Issue brief: re-examining the Indo-Nepal Saptakoshi Dam Project. Indian Council of World Affairs, New Delhi

Shrestha HM (1966) Cadastre of potential water power resources of less studied high mountainous regions, with special reference to Nepal. Dissertation, Moscow Power Institute

Shrestha RB (2016) Nepal's water resources: blessing or curse? HydroNepal 19:11-15

Shrestha HM (2017) Facts and figures about hydropower development in Nepal. HydroNepal 20:1-5

Swyngedouw E (2009) The political economy and political ecology of the hydro-social cycle. J Contemp Water Res Educ 142:56-60

Thapa B (2019a) State sponsored dam. Annapurna post. http://annap urnapost.com/news/130217. Accessed 10 Jan 2020

Thapa B (2019b) India's water politics. Annapurna post. http://annap urnapost.com/news/123046. Accessed 10 Jan 2020

Tipchanta D (2012) The scramble for Africa's oil: a blessing or a curse for African states?. Dissertation, University of Nottingham

Waslekar S (2011) The Blue piece: rethinking Middle East Water. Strategic foresight group. Lifon Industries. https://www.eda.admin.ch/ dam/deza/en/documents/publikationen/Diverses/198458-the-bluepeace_EN.pdf. Accessed 4 Nov 2019

Wolf AT (1998) Conflict and cooperation along international waterways. Water Policy 2:251-265

Yoffe S, Wolf AT, Giordano M (2003) Conflict and cooperation over international freshwater resources: indicators of basins at RISR. J Am Water Resour Assoc 39(5):1109-1126

Zeitoun M, Allan J (2008) Applying hegemony and power theory to transboundary water analysis. Water Policy 10(2):3-12 
Zeitoun M, Mirumachi N (2008) Transboundary water interaction: reconsidering conflict and cooperation. Int Environ Agreem Polit Law Econ 8:297-316

Zeitoun M, Warner J (2006) Hydro-hegemony-a framework for analysis of trans-boundary water conflicts. Water Policy 8(5):435-460

Zeitoun M, Mirumachi N, Warner J (2010) Transboundary water interaction II. International Environmental Agreements. https:// www.researchgate.net/publication/228572068_Transboundary_
water_interaction_II_soft_power_underlying_conflict_and_coope ration/link/0c96052d5751894d69000000/download. Accessed 2 Feb 2020

Publisher's Note Springer Nature remains neutral with regard to jurisdictional claims in published maps and institutional affiliations. 